\title{
Ten Minutes with Dr Linghang Wang, Director of Infectious Diseases Emergency, Deputy Director of the Research Institute of Infectious Diseases, Beijing Ditan Hospital
}

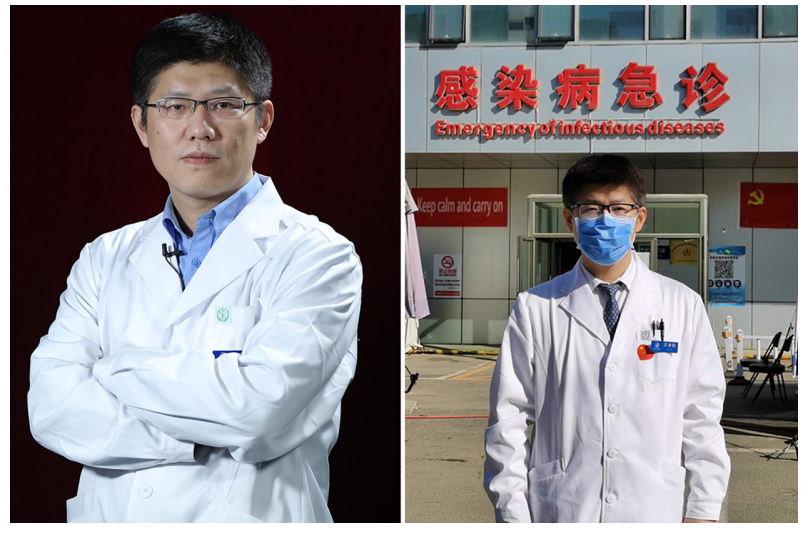

FIRST AND FOREMOST, ARE THERE ANY KEY LEADERSHIP MESSAGES YOU WANT TO GET OUT TO OUR READERSHIP?

We are dealing with a totally new pathogen and a global pandemic. In such a situation I think it is very important for the clinical leader to maintain critical thinking and a 'big picture' vision of the overall situation of the pandemic. This includes understanding the origin of the virus, the clinical characteristics and spectrum of the disease, the sensitivity and specificity of current diagnostic tests, and any potentially effective antiviral medicines, even while mobilising clinical colleagues to participate in the battle against the virus. Keeping the whole clinical team informed, safe and stable is a must-do for any clinical leader confronting a novel emerging infectious disease.

\section{TELL US A LITTLE BIT ABOUT YOUR LEADERSHIP ROLE AND HOW IT IS CHANGING AS A RESULT OF THE PANDEMIC?}

I run the Emergency Department, and organise the day's work in our Fever Clinic. Before the pandemic, each winter the biggest burden was influenza. We have rapid tests for this, to differentiate influenza from other causes of respiratory illness. Things started to change at the end of last year, when we heard of some pneumonia cases of unknown aetiology in Wuhan. I guessed the pathogen could be some kind of coronavirus, and because I know Wuhan has a strong medical system and a good virus research institute, I thought that if the virus was like that causing severe acute respiratory syndrome (SARS), it would be controlled well at the city level. When the pathogen sequence was published, it confirmed a novel coronavirus, now called SARS-CoV-2. Once the reports of exported cases emerged, with evidence of strong transmissibility, I felt the virus would enter Beijing soon.

It has been our routine policy, for a long time, for all patients and staff in the Fever Clinic to wear a surgical mask. Knowing this was a SARS-like coronavirus, I began to urge all my colleagues in the Emergency Department to wear an N95 respirator, and be vigilant for patients attending the Fever Clinic who had a travel history from Wuhan. Several days later, we began to deploy a nucleic acid test in our hospital, guided by technical support and reverse transcriptase polymerase chain reaction (RT-PCR) test reagents provided by the China Centre for Disease Control and Prevention. Almost the same day, the first suspected case was confirmed in the Fever Clinic. We moved to asking all doctors

\section{Biography}

Dr Linghang Wang, MD PhD, is Director of Infectious Diseases Emergency, and Deputy Director of the Research Institute of Infectious Diseases, at Beijing Ditan Hospital, Capital Medical University, Beijing, China.

He has been working as a clinical doctor in Beijing Ditan Hospital since 1998. His research interests focus on the immunological mechanism and genetic determinants for the susceptibility and/or disease progression of various infectious diseases including HIV/AIDS, influenza, Ebola and other infectious diseases.

His publications include papers in Clinical Infectious Diseases, Annals of Internal Medicine, and PlosOne.

and nurses to wear a protective suit, gloves and goggles when working in the clinic. As more information was published and national guidelines for diagnosis and therapy were formulated, we began to focus on developing and updating knowledge about COVID-19.

I now lead a team screening for, and treating, COVID-19. I have had to keep my knowledge updated along the way, in order to be able to explain the current strategy we use. Every time there has been a clinical question, I am the final judge and consultant doctor. As the burden of screening these imported cases became more and more severe, I have had to recruit more doctors and nurses to this team. This has involved asking more volunteers to participate in the work.

\section{WHAT EVENTS IN YOUR PAST EXPERIENCE ARE MOST INFORMING YOUR LEADERSHIP IN THIS PANDEMIC?}

I trained as an Infectious Diseases specialist, and was involved in the SARS outbreak of 2003, at which point I was an attending doctor in an intensive care unit (ICU). Then in 2009-2010 I was involved in the influenza H1N1 pandemic response, leading a special group deciding how to organise the processes and procedures for caring for patients with influenza. I am an expert advisor on public health issues to the Chinese Government Ministry of Health. Earlier this year I was invited to the Ministry of Foreign Affairs to advise on the prevention and management of any infectious disease emergency which might happen in Chinese embassies and consulates, and was asked to draft the response plan for them. All these experiences have been helpful in the current situation. I also find my experience as a clinical investigator helpful; I know how to coordinate a large team, how to keep calm and to think ahead.

\section{WHAT ARE THE BIGGEST CHALLENGES YOU FIND?}

For me the leadership challenges flow from the biology. This novel coronavirus is tricky, with more and more evidence emerging that even younger people can have severe illness, and that sometimes transmission can occur silently, that is, from asymptomatic people. And even if there is a vaccine eventually, we will still face the possibility of vaccine failure due to the inherent variability of 
RNA virus replication leading to mutant strains. All these issues require a very dynamic approach to infection prevention and control as our understanding changes, as well as creating great uncertainty until we have the answers. Leaders have to manage this uncertainty in the messages they are giving out.

\section{ANY PARTICULAR SURPRISES?}

At the very beginning of the outbreak, the medical resources came under huge pressure in Wuhan due to the high medical demands. The crude mortality was very high. In a very short time, a firm public health determination was made, and Wuhan was locked down over one night. Thousands of doctors and nurses were mobilised to go into Wuhan to care for the large number of patients in the module hospital, and where the critically ill patients had accumulated the most. Through widespread education and communication, the general population began to wear masks and stay at home. I was totally surprised by the speed of this rapid response and the spirit of cooperation.

\section{ARE YOU SEEING ANY BEHAVIOURS FROM COLLEAGUES THAT ENCOURAGE OR INSPIRE YOU?}

Some young medical doctors and nurses lack the experience to deal with such a large-scale emerging and novel infectious disease, and despite that, they have still been going to the front line to work without any hesitation. And after a long day of hard work, they have chosen to stay at the office to rest, rather than take the risk of transmitting the virus to their families. When the ward was crowded by students who had returned with COVID-19 contracted overseas, the nurses prepared a lot of national flag logos and assigned one to everyone-the nervous atmosphere suddenly calmed down, and everyone began to show more patience and a spirit of cooperation.

\section{HOW ARE YOU MAINTAINING KINDNESS AND COMPASSION?}

It's really important that we all remember that the common enemy is not the patient, but the tricky virus. The pandemic is a real disaster for the whole of humanity, not just for people in one city, in one province, or just in one country. In order to control the pandemic successfully, we need to unite, through joint prevention and control efforts. I think humanistic care is always the basic requirement for a doctor. I find 'Occasionally cure, always care', to be a good motto.

\section{ARE THERE ANY IDEAS OR READINGS THAT YOU FIND HELPFUL FOR INSPIRATION AND SUPPORT THAT YOU WOULD RECOMMEND TO OTHERS?}

The history of humankind is a history of persevering, of fighting against natural disaster and unexpected difficulties. Stay well and be well. Always keep calm and carry on. We have 'one Earth, one health', and only by cooperation and solidarity can we, humankind, hope to defeat and control our common enemy, the tricky coronavirus SARS-CoV-2.

\section{WHAT ARE YOU LOOKING FOR FROM YOUR LEADERS?}

I am looking for enough support from my leaders. On the one hand, spiritual support; we are all together fighting the virus, we need timely encouragement, and each time there is a difficulty, the leaders should be there, ready to help solve the problem. On the other hand, strategic support; the leaders should think ahead, and have good skills to organise the whole battle, getting all the associated departments working together, and changing policy and strategy flexibly as the epidemic evolves. In this way, we can avoid confusion and anxiety, and we can focus on what we, everyone in this entire battle chain, should be doing.

Linghang Wang, ${ }^{1}$ Anthony Berendt ${ }^{2}$

${ }^{1}$ Infectious Diseases Emergency, Capital Medical University Affiliated Beijing Ditan Hospital, Beijing, China

${ }^{2}$ Oxford, UK

Correspondence to Dr Anthony Berendt, Oxford, UK; a.berendt@ntlworld.com

Twitter Anthony Berendt @tony_berendt

Funding The authors have not declared a specific grant for this research from any funding agency in the public, commercial or not-for-profit sectors.

Competing interests None declared.

Patient consent for publication Not required.

Provenance and peer review Not commissioned; internally peer reviewed.

Data availability statement No data are available.

(C) Author(s) (or their employer(s)) 2020. No commercial re-use. See rights and permissions. Published by BMJ.

\section{Check for updates}

To cite: Wang L, Berendt A. BMJ Leader 2020;4:94-95.

Received 14 April 2020

Accepted 14 April 2020

Published Online First 27 April 2020

BMJ Leader 2020;4:94-95.

doi:10.1136/leader-2020-000263 